\title{
LAND EVALUATION FOR BARLEY CULTIVATION IN AL-NOAMANIYA DISTRICT - IRAQ BY USING REMOTE SENSING AND GEOGRAPHIC INFORMATION SYSTEMS
}

Prof. Dr. Saleem Y. Jamal

University of Baghdad - College of Arts

DOI: $10.37648 /$ ijrssh.v10i03.024

Received: 19 $9^{\text {th }}$ June, 2020; Accepted: 08th July, 2020; Published: 29th July,2020

\begin{abstract}
Land evaluation is the assessment of land performance when used for a particular purpose. The research aims to evaluate Barley cultivation in Al-Naamaniya District in Wasit Governorate - Iraq at present (actual), and in the future (potential) after major improvements possible. Applying remote sensing for land cover and land use classification, it is urban or built-up land occupies $9 \%$, agricultural land $75 \%$, rangeland $1 \%$, water $2 \%$, wetlands $8 \%$, barren land $5 \%$ of the total study area. Applying geographic information system in the input and editing spatial and attribute data, for building data bank of the land resources, land characteristics, and Barley requirements in the study area. Processing data (administration, analyzing) for actual and potential land suitability classification for barley cultivation in the study area. Output and display the results which showed that the actual Barley suitability classification in the study area is S1, S2, S3, and N1 which covered an area of 8\%, 50\%, 30\%, and 12\% respectively for each category. It is possible to repair some of the limitations for Barley cultivation in the future to change suitability classification to S1, and S2, which covers an area 93\%, and 7\% respectively for each category in the study area.
\end{abstract}

Keyword: Land Evaluation, Remote Sensing, Geographic Information System, Barley.

\section{INTRODUCTION}

Land Evaluation is an assessment of land performance when used for a specific purpose ${ }^{1}$; it aims to choose the optimum land use for each land unit ${ }^{2}$, taking into both physical and human considerations, and environmental resources conservation from degradation to achieve sustainable land use $^{3}$. The increasing and continuous pressure on natural resources to meet the miscellaneous human needs, and the limited supply of resources which decreasing in quantity and quality ${ }^{4}$, As well as climate change and its threat to food security ${ }^{5}$, needs proper management, efficient policy, and put appropriate plans for Sustainable development, which based on surveying and inventorying natural, human and economic land resources, and determine the types of land use and land cover and the requirements and limitations of each land-use types ${ }^{6}$.

The research aims to evaluate the suitability of land characteristics for barley cultivation in AlNoamaniya district in Wasit Governorate at present (actual), and in the future (potential) after making possible reclamation and improvements, by comparing between the barley requirements and estimate the Index of limitation, with land use resources in the form of the 
land characteristics: climatic, landforms, water resources, soil, inputs level and the management operations of production. The main research problems and questions can be worded as follows:

- What are the categories of land use/land cover, and land utilization types in the study area?

- What are the requirements and limitations of barley cultivation in the study area?

- What is the method and technique of building spatial and descriptive databases (data bank), to land evaluate and land characteristics suitability classification at present and in the future for barley cultivation in the study area?

To responding the research problem and questions above, the research assume to apply remote sensing to survey the land resources, and classification of land use and land cover in general and agricultural land use in particular, depending Anderson classification system for land use and land cover use with remote sensing data ${ }^{7}$. Applying a combination of limitation method and parametric approach for land evaluation $^{8}$, FAO method for land suitability classification $^{9}$, land evaluation for rainfed agriculture ${ }^{10}$, land evaluation for irrigated agriculture ${ }^{11}$. Applying geographic information system for entering and saving spatial and descriptive data for land resources, categories of land use and land cover, the requirements of barley cultivation in the study area, now data bank ready for processing and analysis, then building a computer model for actual land suitability and potential land suitability for Barley cultivation in the study area.
Finally the output and display the results in the softcopy and hardcopy formate to assist farmers and decision-makers in adopting appropriate spatial decisions for the study area and the output of this research become an input to the subsequent researches in the future.

\section{STUDY AREA}

The study area is located in the southeastern part of central Iraq, inside the floodplain; the Tigris River passes in the northern parts of the study area, figure (1) show the location of the study area. Administratively Al-Noamaniya District is located in Wasit Governorate; it is bordered on the north by AlDubouni sub-district, from the northeastern Jassan subdistrict and Al-Kut district center, from the eastern AlAhrar sub-district, from the south Al-Qadisiya Governorate, from the southwestern Babylon Governorate, from the west and northwest, AlShehamiya and Al-Zubaidiya sub-district ${ }^{12}$. Geographically study area located between latitudes of $\left(32^{\circ} 25^{\prime} 17^{\prime \prime}-32^{\circ} 46^{\prime} 39^{\prime \prime}\right)$ North and longitudes of ( $45^{\circ}$ $\left.22^{\prime} 03^{\prime \prime}-45^{\circ} 32^{\prime} 52^{\prime \prime}\right)$ East $^{13}$.

The study area occupied an area of $946 \mathrm{~km}^{2}$ (94600 ha.), a percentage of $5.5 \%$ of the total area of Wasit Governorate $17,153 \mathrm{~km}^{2}$ (1715.300 ha. $)^{14}$. The study area includes 33 counties, table (1) and figure (2) showing the spatial distribution of the names and numbers of the county in the study area ${ }^{15}$, and the areas that occupy ${ }^{16}$.
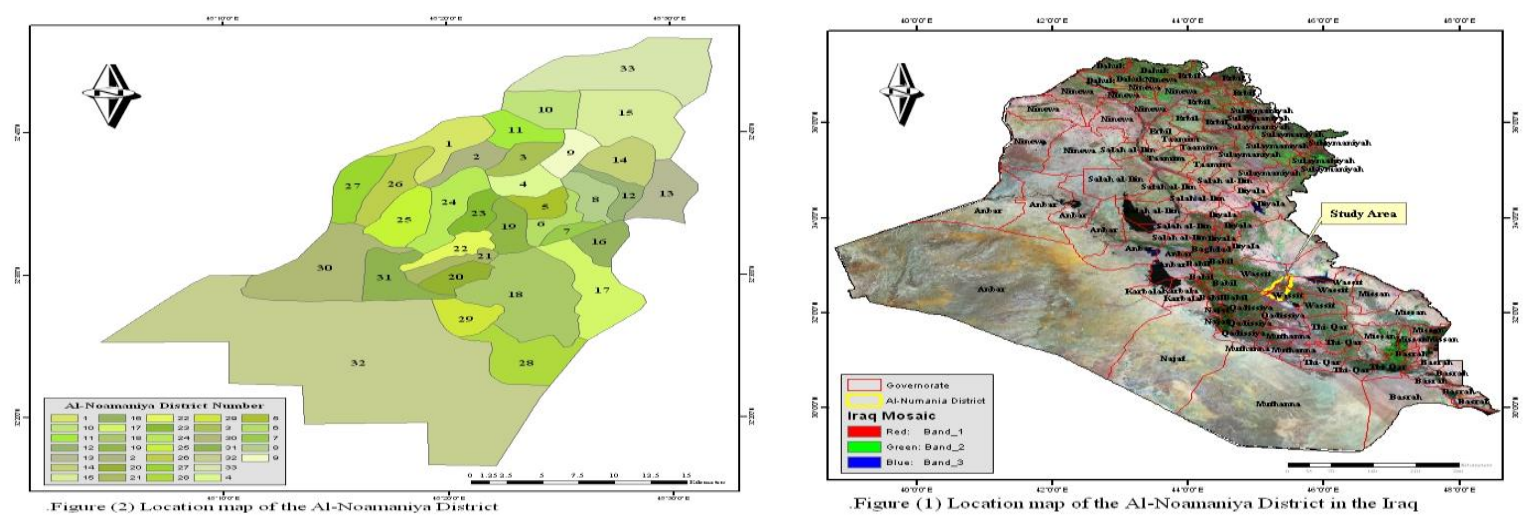
Table (1) County of Al-Noamaniya District

\begin{tabular}{|c|c|c|c|c|c|c|c|}
\hline \begin{tabular}{|l} 
County \\
No.
\end{tabular} & County Name & $\begin{array}{l}\text { Area } \\
\text { ha. }\end{array}$ & $\begin{array}{l}\text { Area } \\
\%\end{array}$ & $\begin{array}{l}\text { County } \\
\text { No. }\end{array}$ & County Name & $\begin{array}{l}\text { Area } \\
\text { ha. }\end{array}$ & $\begin{array}{l}\text { Area } \\
\%\end{array}$ \\
\hline 1 & Abu Jalaj & 2270.4 & 2.4 & 18 & Al-Bagliah & 5959.8 & 6.3 \\
\hline 2 & Samar & 1135.2 & 1.2 & 19 & Al-Noamaniya & 1419.0 & 1.5 \\
\hline 3 & Barhujah & 1135.2 & 1.2 & 20 & Al-Bekeretain & 1040.6 & 1.1 \\
\hline 4 & Shalat and Mumalah & 1229.8 & 1.3 & 21 & Abu Jamus & 851.4 & 0.9 \\
\hline 5 & Al-Daar, Jubah and Tanuh & 946.0 & 1 & 22 & Al-Iftah & 1040.6 & 1.1 \\
\hline 6 & $\begin{array}{l}\text { Al-Sahriah, Dahilah and Al- } \\
\text { Rakah }\end{array}$ & 851.4 & 0.9 & 23 & Ghobeishi & 1040.6 & 1.1 \\
\hline 7 & $\begin{array}{l}\text { Hlehal, Al-Betar and Al- } \\
\text { Hamariah }\end{array}$ & 473.0 & 0.5 & 24 & Al-Musaihia & 2270.4 & 2.4 \\
\hline 8 & Al-Meha & 1324.4 & 1.4 & 25 & $\begin{array}{l}\text { Ahmadiya, Akriniyat and } \\
\text { Al-Balha }\end{array}$ & 1986.6 & 2.1 \\
\hline 9 & Aum Al-Reash & 1135.2 & 1.2 & 26 & Muawiah & 1892.0 & 2 \\
\hline 10 & Abu Ghraib Al-Emeriya & 1892.0 & 2 & 27 & Aum Jekair & 1892.0 & 2 \\
\hline 11 & Samar Al-Ameriya & 1419.0 & 1.5 & 28 & $\begin{array}{l}\text { Bzaiz Awinah and Aum } \\
\text { Beat }\end{array}$ & 3027.2 & 3.2 \\
\hline 12 & Al-Shazi Al-Karbi & 946.0 & 1 & 29 & Bzaiz Sbalah & 1419.0 & 1.5 \\
\hline 13 & Al-Shazi Al-Sharki & 2081.2 & 2.2 & 30 & Bzaiz Al-Musahihia & 5108.4 & 5.4 \\
\hline 14 & Al-Shazi Al-Ausat & 1892.0 & 2 & 31 & Aum Sejyan & 2081.2 & 2.2 \\
\hline 15 & Rimet Shazi and Abu Sameej & 4257.0 & 4.5 & 32 & Arazi Al-Jazirah & 29704.4 & 31.4 \\
\hline 16 & Wanis and Aubeed & 1229.8 & 1.3 & 33 & Arazi Al-Jazira & 6243.6 & 6.6 \\
\hline 17 & $\begin{array}{l}\text { Al-Had, Al-Katabia and } \\
\text { Wabeter Askar }\end{array}$ & 3405.6 & 3.6 & Total & & 94600 & 100 \\
\hline
\end{tabular}

\section{CLIMATE}

Study area represents a hot sub desertic climate; it is characterized by short cool winter and long hot summers and short spring and autumn season, according to Papadakis the climate classification in the study area is 3.272 hot subtropical desert ${ }^{17}$, according to Koppen the climate classification in the study area is hot arid desert $(\mathrm{BWh})^{18}$. Climatic characteristics have the main influence in assessing the land suitability for barley cultivation, the most important climatic characteristics affecting barley cultivation in the study area are temperature, rainfall, humidity, and evaporation, have been used to indicate the climate conditions in the study area. By using the ArcGIS software and depending on the Thission Polygon, which showed that the study area falls within the influence of the Kut climate station ( Al-Kut Climate Station, Station No.664, Latitude $32^{\circ} 30^{\prime}$, Longitude $45^{\circ} 49^{\prime}$, Elevation $\left.19 \mathrm{~m}\right)$ follows to the Iraqi Meteorological Organization for the period (1988-
$2019)^{19}$, to depend upon in the analysis of the direction of spatial variation and temporal change of climate characteristics in the study area.

\subsection{Temperature}

Solar radiation is the main source of energy in the atmosphere, and the intensity and amount of solar radiation determine the general distribution of temperatures on the Earth's surface. Table (2) showing the annual mean temperature is $24^{\circ} \mathrm{C}$, monthly mean temperatures increasing to reach the hottest in July $36.9^{\circ} \mathrm{C}$, after which they decrease to reach their coldest at $12.6^{\circ} \mathrm{C}$ in January. The mean annual maximum and minimum temperatures are $31^{\circ} \mathrm{C}$ and $17^{\circ} \mathrm{C}$ respectively, the monthly mean maximum and minimum temperatures are $45.5^{\circ} \mathrm{C}$ in August the hottest month, and $6.2^{\circ} \mathrm{C}$ in January the coldest month, figure (3) showing the monthly distribution of temperature, figure (4) showing the spatial distribution of temperatures decrease from the northeast to southwest in the study area. 
Table (2) Mean Monthly Temperatures ( $\left.{ }^{\circ} \mathrm{C}\right)$ Kut Climate Station

\begin{tabular}{|l|l|l|l|l|l|l|l|l|l|l|l|l|l|}
\hline $\begin{array}{l}\text { Month } \\
\text { Mean }\end{array}$ & Jan. & Feb. & Mar. & Apr. & May & Jun. & Jul. & Aug. & Sep. & Oct. & Nov. & Des. & Ann. \\
\hline Mean & 11 & 13 & 17.7 & 24.3 & 30.8 & 34.9 & 36.9 & 36 & 32.3 & 26.4 & 18.2 & 12.6 & 24 \\
\hline Max. & 16.4 & 20 & 25 & 31.3 & 38.2 & 42.9 & 45 & 45.5 & 41.5 & 35 & 25 & 19 & 31 \\
\hline Min. & 6.2 & 8 & 12.1 & 17.1 & 23 & 26 & 28.1 & 27 & 24 & 18 & 12.1 & 8.3 & 17 \\
\hline
\end{tabular}
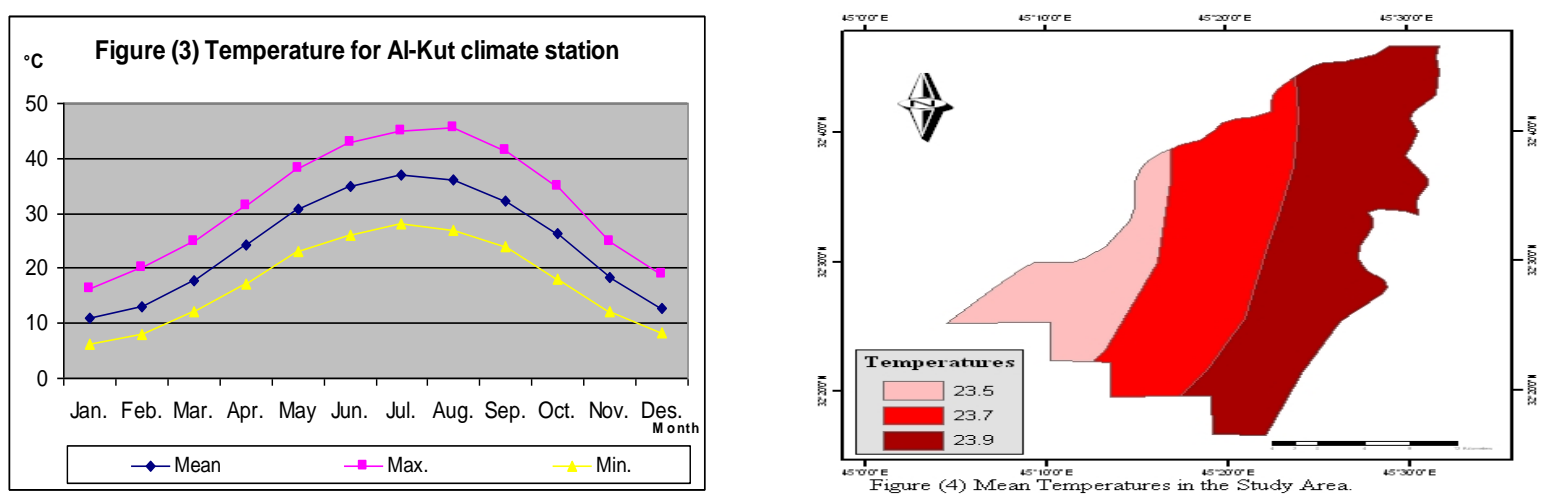

\subsection{Relative Humidity, Rainfall, and Evaporation}

Relative Humidity is one of the main climatic elements in the formation of condensation and precipitation, and evaporation is a source of Relative Humidity. Table (3) showing that the rate of annual relative humidity is $44 \%$; the monthly rates of relative humidity are increasing to reach their highest of $71 \%$ in January, and then they are decreasing to reach their lowest of $23 \%$ in July.

The total annual rainfall reached $133 \mathrm{~mm}$; most of which is received from October to May, and the months of Jun to September remain dry. Figure (5) shows the spatial distribution of rainfall decrease from the northeast to the southwest in the study area.

The total annual of evaporation reached $3906 \mathrm{~mm}$, the monthly evaporation increasing to reach the highest in July 647 $\mathrm{mm}$, then decreasing to reach its lowest in January $71 \mathrm{~mm}$. Figure (6) showing the monthly average of rainfall and evaporation from May to October about $9 \%$ and $77 \%$, while from November to April about $91 \%$ and $23 \%$ respectively.

Table (3) Average Relative Humidity, Rainfall, and Evaporation for Al-Kut Climate Station

\begin{tabular}{|l|l|l|l|l|l|l|l|l|l|l|l|l|l||}
\hline $\begin{array}{l}\text { Month } \\
\text { Mean }\end{array}$ & Jan. & Feb. & Mar. & Apr. & May & Jun. & Jul. & Aug. & Sep. & Oct. & Nov. & Des. & Ann. \\
\hline Relative Humidity (\%) & 71 & 62 & 55 & 44 & 32 & 25 & 23 & 25 & 27 & 38 & 56 & 67 & 44 \\
\hline Raifall (mm) & 29.1 & 21 & 19 & 15 & 7.6 & 0 & 0 & 0 & 0 & 3.3 & 18 & 20 & 133 \\
\hline Evaporation (mm) & 71 & 117 & 197 & 283 & 440 & 596 & 647 & 597 & 442 & 299 & 140 & 77 & 3906 \\
\hline
\end{tabular}



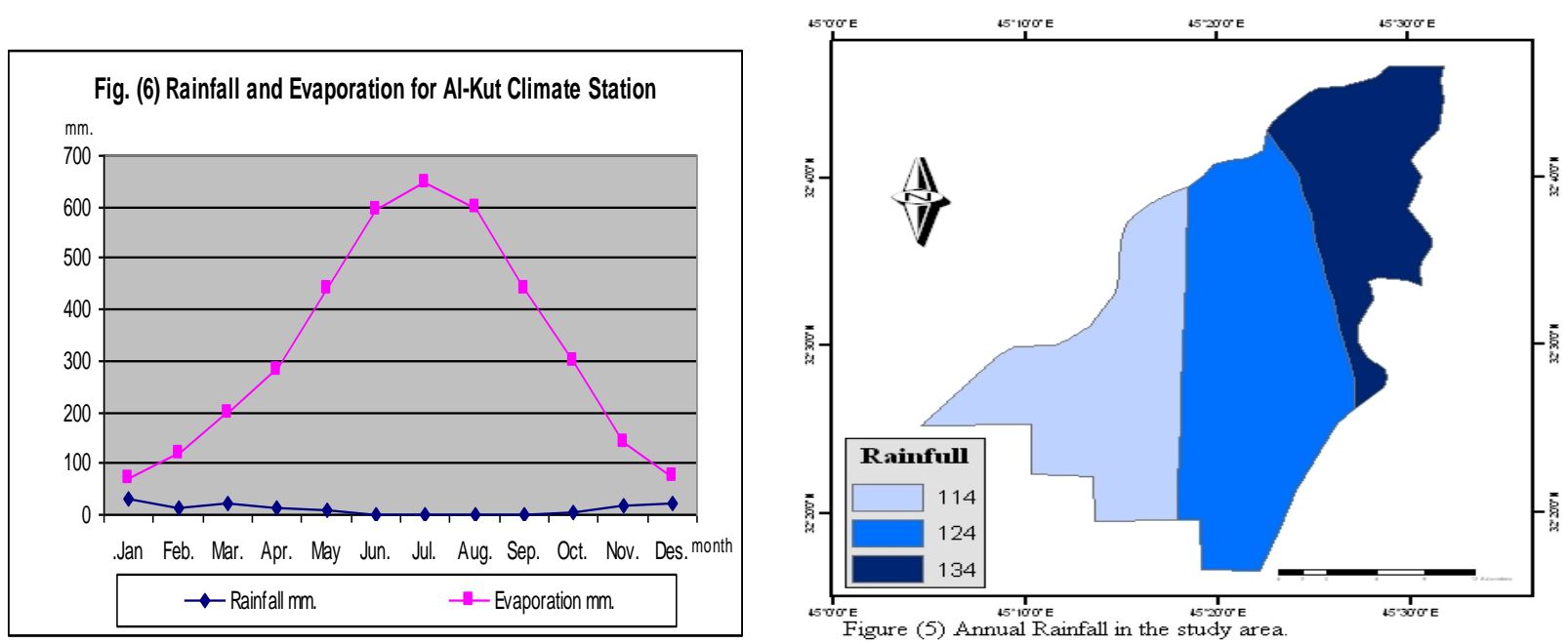

\section{LANDFORM}

Landform features are a direct and indirect influence on the land evaluation for barley cultivation in the study area. The topography is reflecting the geological, geomorphological and climatic conditions in the study area it was part of the lower Mesopotamian aggregation plain, which formed during the Holocene and recent period mainly from the river sediments, which derived from the north and northeast mountains and hills, of the Mesozoic and Tertiary formation which consist dominantly from limestones and argillaceous sediments ${ }^{20}$. The most important geomorphological formations in the study area are the sediments of the alluvial plain, levees, sediments of shallow depressions, point bars, sediments of marshes, and sediments of human activity ${ }^{21}$.

By using the 3D analyst extension within the ArcGIS software to reclass the digital elevation model ${ }^{22}$, figure (6) and Table (4) showing the study area is flat to almost flat and the notable landforms are the levees and irrigation channels. The height varies in the study area from $4 \mathrm{~m}$ to $40 \mathrm{~m}$, reclassified the elevations into three categories as:

- The first category (4-20) m occupy 27434 ha (29\%) of the total study area and covered the shallow depressions.

- The second category (21-22) m occupy 37840 ha (40\%) of the total study area and covered the Tigris river basin.

- The third category (23-40) m occupy 29326 ha (31\%) of the total study area and distributed on the levees and the hight areas near the Tigris river.

Table (4) Category of Elevation and Slope in the study area

\begin{tabular}{|l|l|l|l||}
\hline \hline $\begin{array}{l}\text { Area } \\
\text { Elevation \& Slope }\end{array}$ & Area ha. & Area \% \\
\hline \multirow{4}{*}{$\begin{array}{l}\text { Elevation } \\
(\mathrm{m})\end{array}$} & $4-20$ & 27434 & 29 \\
\cline { 2 - 4 } & $21-22$ & 37840 & 40 \\
\cline { 2 - 5 } & $23-40$ & 29326 & 31 \\
\cline { 2 - 5 } $\begin{array}{l}\text { Slope } \\
(\%)\end{array}$ & Total & 94600 & 99.5 \\
\hline
\end{tabular}

Using the digital elevation model to prepare the slopes map for the study area by the 3D Analyst extension ( Surface Analysis - Slope) in the ArcGIS software, to reclassify the slopes into two categories according to the USDA ${ }^{23}$, figure (7) and table (5) showing the categories as:

- The first category flat - almost flat (0 - 2) \% occupied 94127 ha $(99.5 \%)$ of the total area, it covers most lands, which is suitable and does not represent a limitation for barley cultivation in the study area.

- The second category Undulating (2 - 8) \% occupied 473 ha $(0.5 \%)$ of the total area; it is spread in the high relatively lands southwest the study area and near the levees of the Tigris river. 

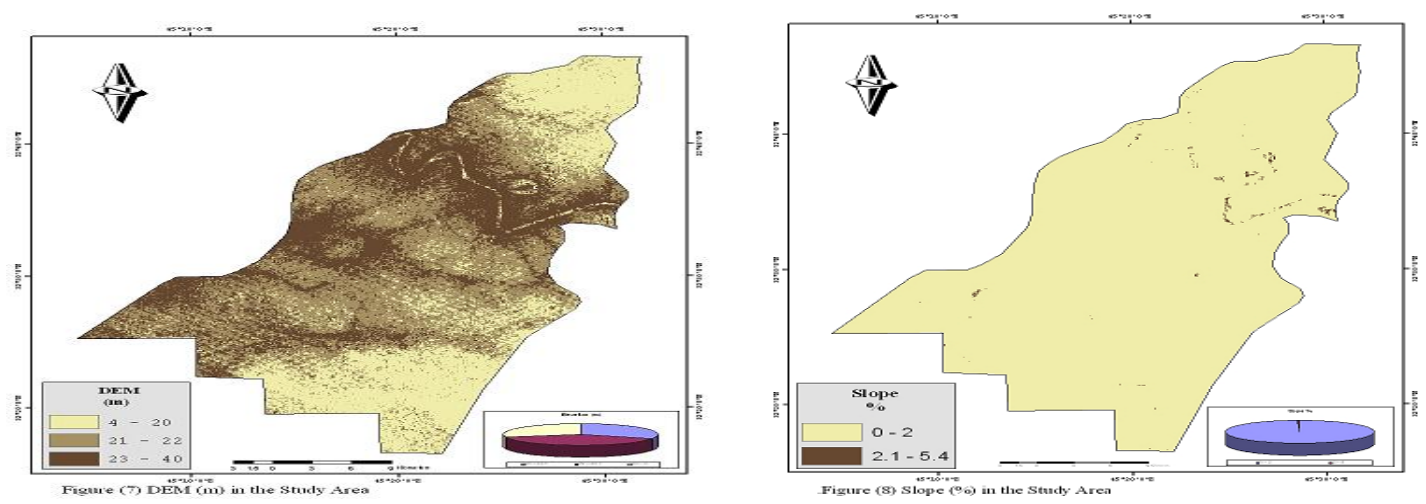

\section{SOIL}

Soil survey and classify, knowing their characteristic is essential in the land evaluation for barley cultivation in the study area. Depending on the Kut climatic station data (tables $2 \& 3$ ) based on the American soil survey staff ${ }^{24}$ and Newhall system so the soil moisture system is Aridic, and the soil temperature system is Hyperthermic ${ }^{25}$. Depending on the morphological, physical, chemical characteristics and the soil humidity and temperature system, classified the soil in the study area into two orders ${ }^{26 \& 27}$ (Entisol, Aridisols), two suborders (Fluvents, Orthids), two great groups (Torrifluvents, Salorthids), six subgroups (Typic, Vertic, Aqueptic, Fluventic, Fluvaquentic, Gypsic), seven family and seven series, table (5) and figure (9) showing the soil classes and it is the spatial distribution.

Table (5) Classification of Soils in the Study Area

\begin{tabular}{|c|c|c|c|c|c|c|c|}
\hline Order & Suborder & Great group & Subgroup & Family & Series & $\begin{array}{l}\text { Area } \\
\text { ha }\end{array}$ & $\begin{array}{l}\text { Area } \\
\%\end{array}$ \\
\hline \multirow{4}{*}{ Entisols } & \multirow{4}{*}{ Fluvents } & \multirow{4}{*}{ Torrifluvents } & \multirow{2}{*}{ Typic } & \begin{tabular}{|l} 
fine- silty, mixed, calcareous, \\
hyperthermic
\end{tabular} & Tigris & 18920 & 20 \\
\hline & & & & \begin{tabular}{|lll} 
fine-silty, mixed, & calcareous, \\
hyperthermic
\end{tabular} & Tunis & 29326 & 31 \\
\hline & & & Vertic & $\begin{array}{l}\text { clayey (fine) over fine silty, mixed } \\
\text { calcareous, hyperthermic }\end{array}$ & $\begin{array}{l}\text { Al- } \\
\text { Wahde }\end{array}$ & 33110 & 35 \\
\hline & & & Aqueptic & $\begin{array}{l}\text { clayey (fine), mixed, calcareous, } \\
\text { hyperthermic }\end{array}$ & Addala & 946 & 1 \\
\hline \multirow{3}{*}{ Aridisols } & \multirow{3}{*}{ Orthids } & \multirow{3}{*}{ Salorthids } & Fluventic & $\begin{array}{l}\text { Clay (fine), Mixed , Calcareous , } \\
\text { Hyperthermic }\end{array}$ & $\begin{array}{l}\text { Al- } \\
\text { Maleh }\end{array}$ & 6622 & 7 \\
\hline & & & Fluvaquentic & $\begin{array}{l}\text { fine-silty over coarse-loamy, mixed } \\
\text { alacareous, hypertherrmic }\end{array}$ & $\begin{array}{l}\text { Hamza- } \\
\text { Kazin }\end{array}$ & 1892 & 2 \\
\hline & & & Gypsic & \begin{tabular}{|l} 
fine silty, mixed, calcareous, \\
hypertherrmic
\end{tabular} & Dilfia & 3784 & 4 \\
\hline
\end{tabular}

Source: - Jawahar L. Sehgal, et al., The soils of the Middle Tigris Project for land use planning, General Establishment for Soil Studies \& Designs, State Organization for Soil \& Land Reclamation, Baghdad, Iraq, 1980.

- Ibrahim J. Mohammad, a Unified National soil Legend for Iraqi Soils, Directorate General of Water Resources Management, Baghdad, 2009. 


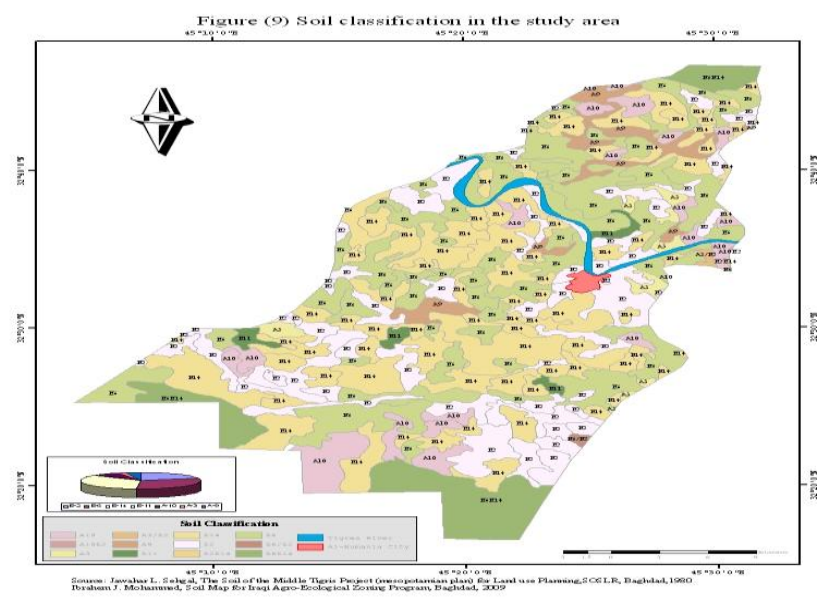

\subsection{Entisol Order}

The Entisol soil is a member of the Fluverts suborder, Torrifluvents great group, three subgroups (Typic, Vertic, and Aqueptic), and four series (Tigris, Tunis, Al-Wahde, Addala). It is a recent undeveloped soil ${ }^{28}$, part of the floodplain of the Tigris River ${ }^{29}$. It covering levees and river basins, it occupies 82,302 ha (87\%) of the total study area.

\section{- Tigris Series}

Tigris series (mapping symbol E-2) is a member of fine-silty, mixed, calcareous, hyperthermic, family of Typic Torrifluvent; soils developed on alluvium derived from the Tigris River, comprise highly porous moderately-well drained with, permeability is moderate. Texture fine silt-loam, the color is darkyellowish-brown to yellowish-brown, structure from massive to subangular blocky. The organic matter varying (1-0.3) \% and irregularly with depth, the ECe value varying (4-8) mmhos/cm and irregularly with depth. Tigris Series occupies 18920 ha (20\%) of the total study area, the soils are found in recent alluvial deposits along the river, and the recent point-bar.

\section{- Tunis Series}

Tunis Series (mapping symbol E-6) is a member of fine-silty, mixed, calcareous, hyperthermic, family of Typic Torrifluvent; soils developed on alluvium derived from the Tigris River comprises very deep soil, well-drained, highly-calcareous, texture silty-clay-loam to clay-loam, color dark-yellowish-brown to brown, structure subangular blocky, the organic matter content varying (1-0.6) \% and irregularly with depth, the ECe value varying (5-13) mmhos/cm. Tunis Series occupies 29326 ha $(31 \%)$ of the total study area, the soils are found in recent alluvial deposits along the Tigris river.

\section{- Al-Wahde Series}

Al-Wahde Series (mapping symbol E-14) is a member of clayey (fine) over fine silty, mixed calcareous, hyperthermic Family of Vertic Torrifluvent, soils developed on alluvium derived from the Tigris River comprises, very deep soils, well-drained with moderate, highly-calcareous, texture silty-clay-loam to silty-clay, color dark-brown to yellowish-brown, structure subangular blocky, the organic matter varying (0.4-1) \% and irregularly with depth, the ECe value varying (4-10) mmhos/cm. Al-Wahde Series occupies 33110 ha $(35 \%)$ of the total study area, the spatial distribution of the soils appears in the basins area.

\section{- Addala Series}

Addala Series (mapping symbol E-11) is a member of clayey (fine), mixed, calcareous, hyperthermic family Aquertic Torrifluvent, soils developed on alluvium derived from the Tigris River comprises, very deep soils, imperfectly-drainage, highly-calcareous, texture heavy silty-clay-loam to silty-clay, color pale-brown to dark-greyish-brown, structure subangular blocky, the organic matter content less than $1 \%$ and irregularly with depth, the ECe value varying (12-17) mmhos $/ \mathrm{cm}$. Addala Series occupies 946 ha (1\%) of the total study area, the spatial distribution of the soils appears on comparatively lower topographic locations in the swampy areas.

\subsection{Aridisols Order}

The Aridisols soil is a member of the Orthids suborder, Salorthids great group, three subgroups (Fluventic, Fluvaquentic, and Gypsic), and three series (Al-Maleh, Hamza-Kazin, Dilfia). It is a recent undeveloped soil covering levees and river basins ${ }^{30}$; it occupies 12298 ha $(13 \%)$ of the total study.

\section{- Al-Maleh Series}

Al-Maleh Series (mapping symbol A10) is a member of clayey (fine), mixed, calcareous, hyperthermic family gypsic salorthid. Soils developed on alluvium derived from the Tigris River comprises very deep soils, moderate-well drained, highly-calcareous, texture heavy silty-clay-loam to silty-clay, color dark-brown to 
yellowish, structure subangular blocky, the organic matter content less than $0.5 \%$ and irregularly with depth, the ECe value more than $24 \mathrm{mmhos} / \mathrm{cm}$. AlMaleh Series occupies 6622 ha $(7 \%)$ of the total study area, the spatial distribution of the soils appears on a lower topographic location in the river basin areas.

\section{- Hamza-Kazin Series}

Hamza-Kazin Series (mapping symbol A3) is a member of fine-silty over coarse-loamy, mixed calcareous, hyperthermic family of Fluvaquentic Salorthid, soils developed on alluvium derived from the Tigris River, very deep soils, Moderately-well to Imperfectly-drained, highly-calcareous, texture clayloam to silty-clay-loam, color dark-yellowish-brown to yellowish-brown, the organic matter about $0.3 \%$ and irregularly with depth, the ECe value varying (30-50) mmhos/cm. Hamza-Kazin Series occupies 1892 ha (2\%) of the total study area, the spatial distribution of the soils confined to levee areas.

\section{- Dilfia Series}

Dilfia Series (mapping symbol A9) is a member of fine silty, mixed, calcareous, hyperthermic family of Gypsic Salorthid, soils developed on alluvium derived from the Tigris River comprises very deep soils, welldrained, calcareous very deep, texture silty-clay loam to silty-loam, color dark-brown to yellowish-brown, structure subangular blocky, the organic matter varying (0.6-0.9) \% and irregularly with depth, the ECe value varying (23-81) mmhos/cm. Dilfia Series occupies 3784 ha $(4 \%)$ of the total study area, the spatial distribution of the soils appears in the northern parts of the study area.

\section{HYDROLOGY}

Water resources are a basic characteristic of land evaluation for barley cultivation in the study area. Water resources include surface water, precipitation, and groundwater.

Rainfall, the most important forms of precipitation, which are few and oscillating, previously studied within the climatic; rainfall quantities are considered few, and oscillatory for barley cultivation.

Tigris River is the main source of irrigation for barley cultivation in the study area, it crosses in the northern parts of the study area, and its length is $36 \mathrm{~km}$. As a result of the flat slope of the surface, the curves abound in the river, which previously explained in the terrain. Dependence on the annual and monthly, Tigris River runoff rates, for the Saray Baghdad and Sadt Al-Kut stations for the period $(1988-2019)^{31}$ the annual discharge is $664 \mathrm{~m}^{3} / \mathrm{sec}$ and $352 \mathrm{~m}^{3} / \mathrm{sec}$ respectively for each, the annual rates varied from year to year, the greatest discharge at 1988 (1692 and 1512$) \mathrm{m}^{3} / \mathrm{sec}$, and the lowest discharge at 2001 (392 and 134) $\mathrm{m}^{3} / \mathrm{sec}$, respectively for each, the change in the annual discharge, as a result of variation in amounts of rain, snow melting and climate change in the world. Also, the monthly rates of Tigris River discharge vary; the Saray Baghdad station recorded the greatest discharge during March $699 \mathrm{~m}^{3} / \mathrm{sec}$ and the lowest discharge during October $617 \mathrm{~m}^{3} / \mathrm{sec}$, Sadt Al-Kut stations recorded the greatest discharge during April $417 \mathrm{~m}^{3} / \mathrm{sec}$ and the lowest discharge during Augustes $295 \mathrm{~m}^{3} / \mathrm{sec}$. Conclude from the above that the monthly discharge of the Tigris River is low at the beginning of the winter agricultural season and rises at the end of it, and The lowest level of discharge is in August and September when summer crops need more water, due to high temperatures and increased evaporation. Therefore, agriculture in the study area depending mainly on the Tigris River and irrigation channels to supply water to the agricultural lands, depending on the free or pumping irrigation systems, and different irrigation methods (basin, furrow, trickle and sprinkle), the total number of pumps 926, which is powered by electricity, diesel, and oil, and with different horsepower ${ }^{32}$. Depending on the salinity classification system in the United States of America ${ }^{33}$, it classified the water of the Tigris River in the study area to the class C3, which is highly salty water and cannot be used without effective drainage canals ${ }^{34}$. Al-Dalamij marshland located in the southern part of the study area, on the right side of the Tigris River with a distance of $26 \mathrm{~km}$, the amount of water vary in it annually and monthly, and the increasing percentage of salts led to limit use for crop irrigation ${ }^{35}$.

As a result of the availability of surface water, the need for groundwater is scarce; especially the quality of the groundwater is medium to high due to the high soluble salts reflect on its uses ${ }^{36}$.

\section{LAND USE AND LAND COVER CLASSIFICATION}

Land use refers to the human activity associated with land, land cover refer to the features pattern located on the land. The classification of land use and land cover is an essential step for assessing land for barley cultivation. Using the Landsat-8 images (Landsat Data Continuity Mission), collected with the sensor (Operational Land Imager), According to the world reference system (WRS-2) path 168 and row 038, for the winter agricultural season at 21-03-2019 
and the summer agriculture season at $25-06-2019^{37}$. Using ERDAS IMAGINE software, with a layer stack tool, spectral bands merged. Based on the administrative study area map, after geometrically matched with the satellite image, extracted study area by using the Subset Image tool. Depending on the Anderson land use and land cover classification system $^{38}$, to build a system for land use and land cover for the study area, by using digital image processing software (ERDAS IMAGINE), and Geographic Information System (ArcGIS), by the series of steps for digital image processing, preprocessing stage, radiometric and geometric correction, spatial and spectral enhancement. Processing stage, by quantitative image classification (unsupervised, supervised) and qualitative image classification (visual interpretation), then integrated by the expert classification method. For more accurate results in the post-processing stage ${ }^{39}$, for land use and land cover categories in the study area.

\subsection{Image Correction}

The image correction aims for getting better data to interpret the image, geometric and radiometric correction is applied to the study area.

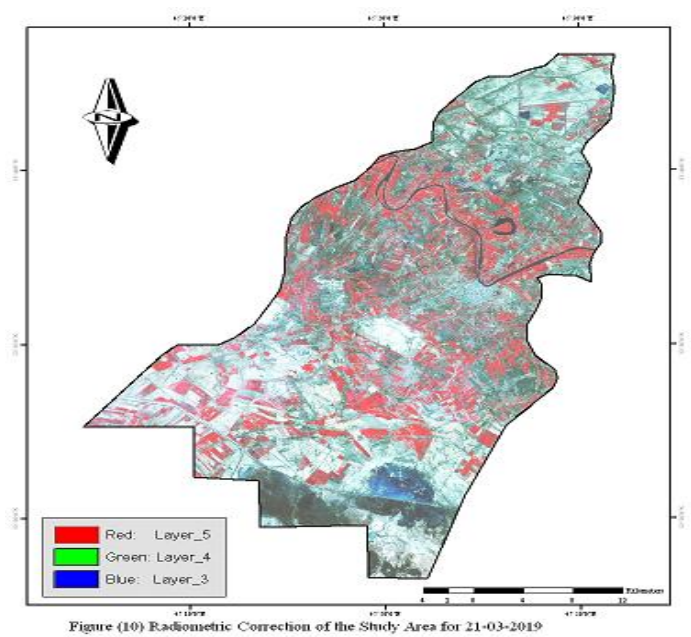

\subsubsection{Geometric Correction}

The geometric correction aims to geometric unify of the satellite images used in the research, with topographic and thematic maps of the study area. By using ERDAS IMAGINE reproject images tool according to WGS 84 UTM zone $38 \mathrm{~N}$ projection according to the nearest neighbor method applied a geometric correction for study area maps.

\subsubsection{Radiometric Correction}

The radiometric correction reduces the contrast of spectral reflectance and changes in the illumination of the land cover between the seasons (winter and summer). The consequence of the seasonal changes in solar elevation angle and the distance between the earth and the sun, to remove the atmospheric effects for scenes matching ${ }^{40}$, used ERDAS IMAGINE software the spatial modeler and model maker to build the radiometric correction model by calculating the digital number for each pixel. Figure (10) showing the radiometric correction for 21-03-2019, Figure (11) shows the radiometric correction for 25-06-2019.

\section{2. Image enhancement}

Image enhancement objective to obtain a new image more compatible than the original image for a specific use ${ }^{41}$, which is making it more appropriate for a particular application ${ }^{42}$. The aim of applied spatial and spectral improvements to improve the visual interpretation of the images in the research.

\subsubsection{Spatial Enhancement}

The resolution merge is one of the spatial enhancements that aim to increase the spatial resolution of the image then improve the ability of visual interpretation. Merged the OLI multispectral bands that low spatial resolution $30 \mathrm{~m}$, are combined with the panchromatic band that high spatial resolution $15 \mathrm{~m}$. Figure (12) showing the resolution merge for 21-03-2019, Figure (13) shows Resolution Merge for 25-06-2019. 

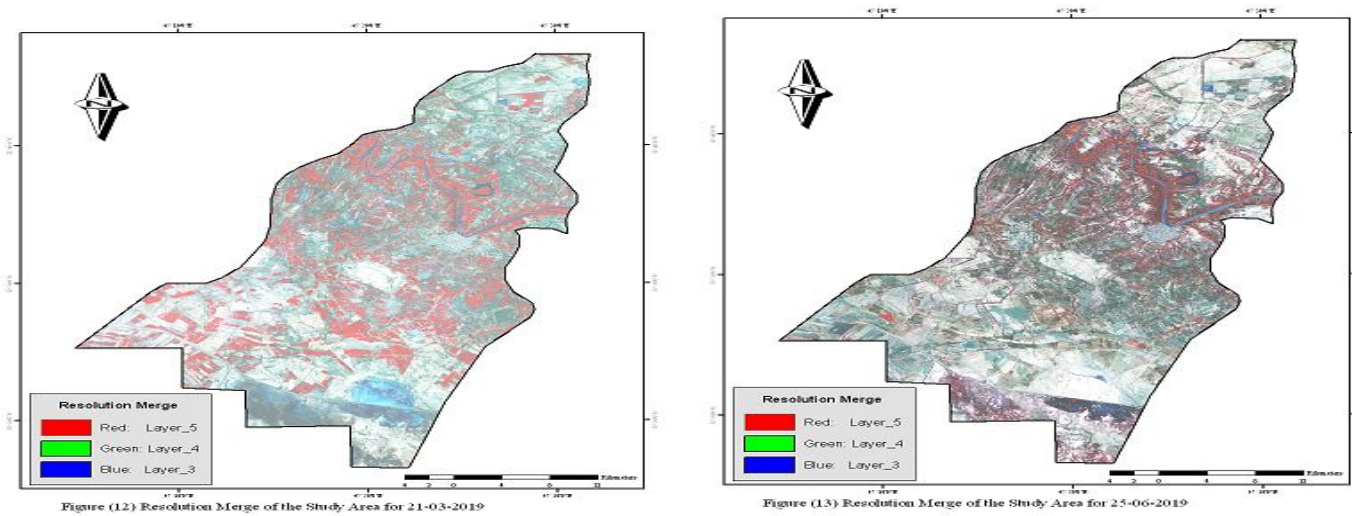

\subsubsection{Spectral Enhancement}

To classify the land use and land cover, there are multiple methods of spectral enhancement. Vegetation indices were used to separate the vegetation cover from the land cover ${ }^{43}$, the vegetation cover appears low reflectance in the red band (R) and high reflectance in the near-infrared (NIR) ${ }^{44}$. Vegetation indices assist in the interpretation process, classification accuracy, classification vegetation types, assessment of crop conditions, estimating the expected production amount, plant condition, water content, biomass, early detection of the problems, and support for precision farming, ... etc ${ }^{45}$. Applied NDVI and SAVI to convert the digital number into a reflectance value of vegetation indices in the study area, by using the metadata for each image used in the research.

\subsubsection{Normalized Difference Vegetation Index}

Approximately about $70 \%$ of the land surface is covered with vegetation ${ }^{46}$, normalized difference vegetation index one of the common used spectral enhancement for surveying and monitoring vegetation cover, the quantity and quality assessment of the vegetation cover $^{47}$, it's status detection, agricultural production forecasting ${ }^{48}$, drought, and degradation monitoring, ... etc ${ }^{49}$.

NDVI is the difference ratio of wavelengths between the near-infrared band (NIR) and the visible red band (R); calculated according to the equation as:

NDVI = (NIR - RED) / (NIR + RED) ... 1

The result of the equation is between -1 and +1 ; positive values correspond to the vegetated area according to their densities and vice versa for negative values non-vegetative areas. Figure (14) showing the NDVI for 21-03-2019, (15) shows the NDVI for 25-06-2019, the spatial distribution of vegetation cover near water resources with different densities, while the other covers occupy the remaining parts of the study area.
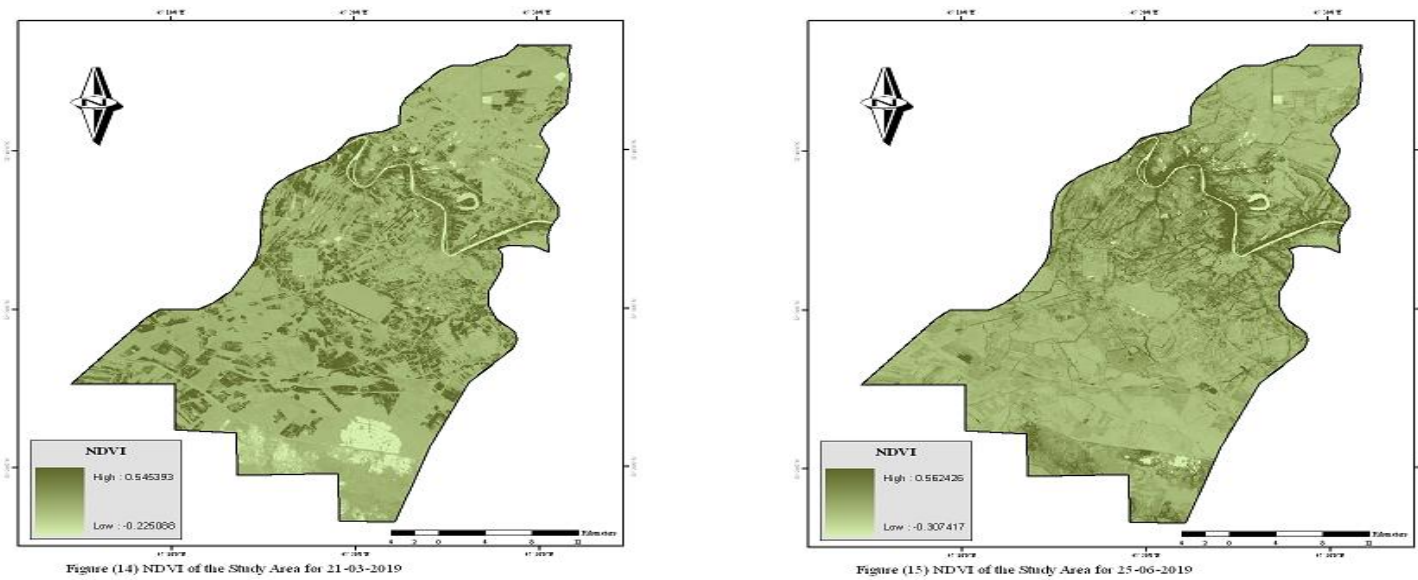

\subsubsection{Soil Adjusted Vegetation Index}

Soil Adjusted Vegetation Index used for enhanced methods to distinguishing vegetation reflection and soil; it is designing to compensate for a soil background in the sparsely vegetated areas ${ }^{50}$. SAVI calculated according to the equation as: 
$\mathrm{SAVI}=(\mathrm{NIR}-\mathrm{RED}) *(1+\mathrm{L}) /(\mathrm{NIR}+\mathrm{RED}+\mathrm{L}) \ldots 2$

Where $\mathrm{L}$ is a correction factor between $0 \& 1$, with a default value is 0.5 (when $\mathrm{L}$ approaches as 0 , SAVI become close to NDVI). Figure (16) showing the SAVI for 21-03-2019, (17) shows the SAVI for 25-06-2019, the spatial distribution of vegetation cover near water resources with different densities, while the other covers occupy the remaining parts of the study area.
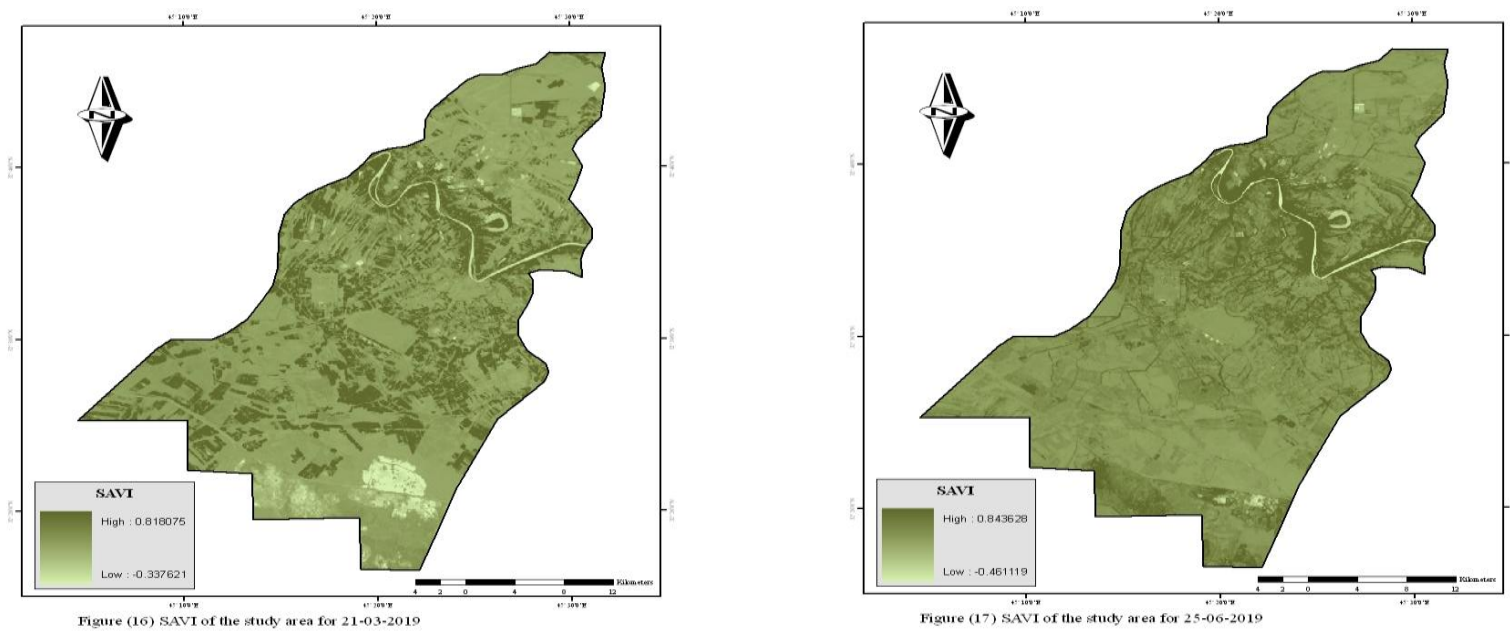

\subsection{Image Classification}

The overall objective of image classification procedures is to categorize all pixels in an image into land use and land cover classes or themes ${ }^{51}$. Depending on the classification methods, the land use and land cover in the study area have been classified using, the quantitative classification method (digital image processing), by applied unsupervised classification and supervised classification, the qualitative classification method (visual image interpretation) by using the elements of visual interpretation, to achieve better results in the classification process, by integration between classification method (quantitative and qualitative) in the expert classification method.

\subsubsection{Unsupervised Classification}

The unsupervised classification used to get a general view of the land use and land cover, especially when there is no familiarity with the studied area. Unsupervised classification distinguishes automatically by applying decision rules ${ }^{52}$, using algorithms to grouping picture elements with identical spectral properties into specific spectral clusters, depending on the Iteration Self Organizing Data Analysis method ${ }^{53}$, then the category is defined based on thematic maps, statistic tables, and field visits, to determine the ground features represented for each category on the image.

Table (6) and figure (18) show the unsupervised classification of the study area for the winter season (21-03-2019), winter crops occupy $24 \%$, orchards $6 \%$, tilth land $18 \%$, fallow land $25 \%$, barren land $17 \%$, and water $10 \%$. Figure (19) show the unsupervised classification of the study area for the summer season (25-06-2019), summer crops occupy $11 \%$, orchards $5 \%$, tilth land $20 \%$, fallow land $30 \%$, barren land $26 \%$, and water $8 \%$.

Table (6) unsupervised classification of the study area

\begin{tabular}{|l|l|l|l|l||}
\hline \multirow{2}{*}{ land use/land cover } & Winter season (21-03-2019) & \multicolumn{2}{l|}{ Summer season (25-06-2019) } \\
\cline { 2 - 5 } & Area ha. & Area \% & Area ha. & Area \% \\
\hline crops & 22704 & 24 & 10406 & 11 \\
\hline orchards & 5676 & 6 & 4730 & 5 \\
\hline tilth & 17028 & 18 & 18920 & 20 \\
\hline fallow & 23650 & 25 & 28380 & 30 \\
\hline barren & 16082 & 17 & 24596 & 26 \\
\hline water & 9460 & 10 & 7568 & 8 \\
\hline total area & 94600 & 100 & 94600 & 100 \\
\hline
\end{tabular}



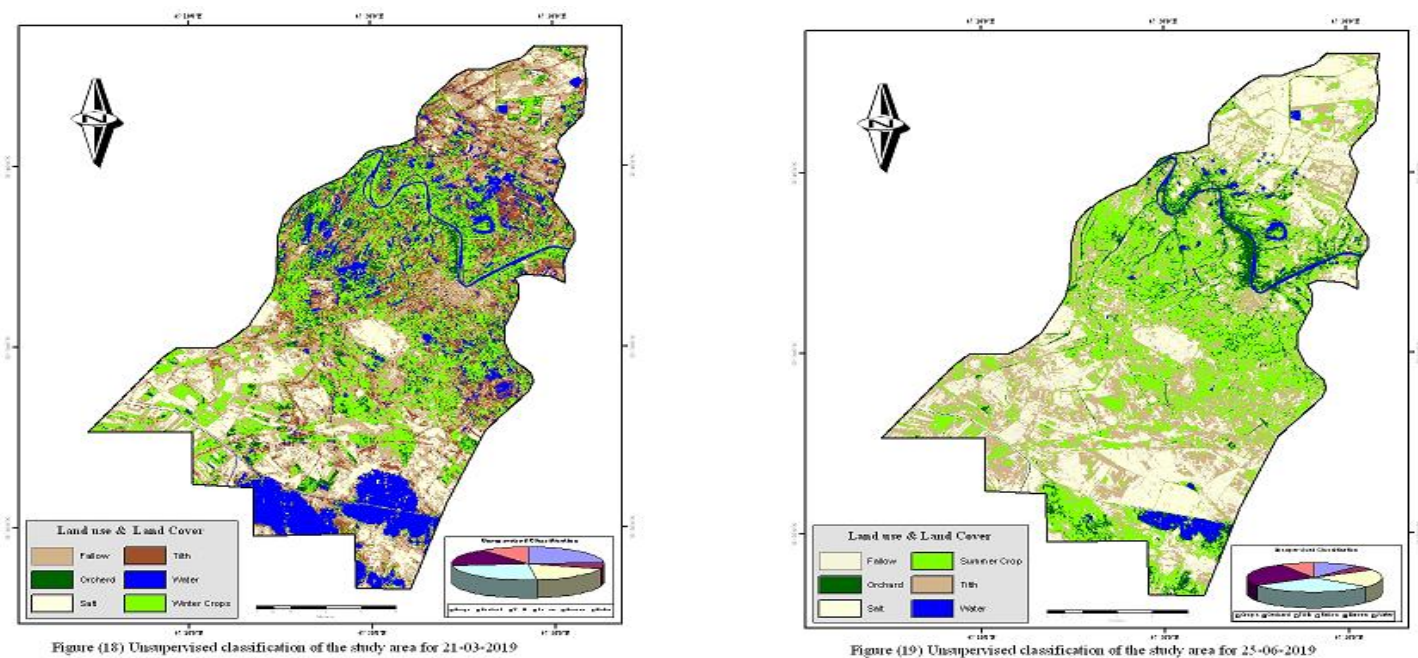

\subsubsection{Supervised Classification}

Supervised classification is used when the interpreter knows the study area; it controls the classification process by training areas, and determines the spectral characteristics of each class expected to be there ${ }^{54}$, using ancillary references such as topographic and thematic maps, statistical data, and unsupervised classification. Training areas were identified using ancillary references then a signature editor file was created, by maximum likelihood method to calculate the training data as a means of estimating averages and variances of the categories then used to estimate the probabilities ${ }^{55}$. Table (7) and figure (20) show the supervised classification of the study area for the winter season (21-03-2019), winter crops occupy $21 \%$, orchards $7 \%$, tilth land $16 \%$, fallow land $30 \%$, barren land $18 \%$, and water $8 \%$. Figure (21) show the supervised classification of the study area for the summer season (25-06-2019), summer crops occupy $9 \%$, orchards $4 \%$, tilth land $22 \%$, fallow land $33 \%$, barren land $25 \%$, and water $7 \%$.

Table (7) supervised classification of the study area

\begin{tabular}{|l|l|l|l|l|}
\hline \multirow{2}{*}{ land use/land cover } & \multicolumn{3}{l|}{ Winter season (21-03-2019) } & \multicolumn{2}{l|}{ Summer season (25-06-2019) } \\
\cline { 2 - 5 } & Area ha. & Area \% & Area ha. & Area \% \\
\hline crops & 19866 & 21 & 8514 & 9 \\
\hline orchards & 6622 & 7 & 3784 & 4 \\
\hline tilth & 15136 & 16 & 20812 & 22 \\
\hline fallow & 28380 & 30 & 31218 & 33 \\
\hline barren & 17028 & 18 & 23650 & 25 \\
\hline water & 7568 & 8 & 6622 & 7 \\
\hline total area & 94600 & 100 & 94600 & 100 \\
\hline
\end{tabular}
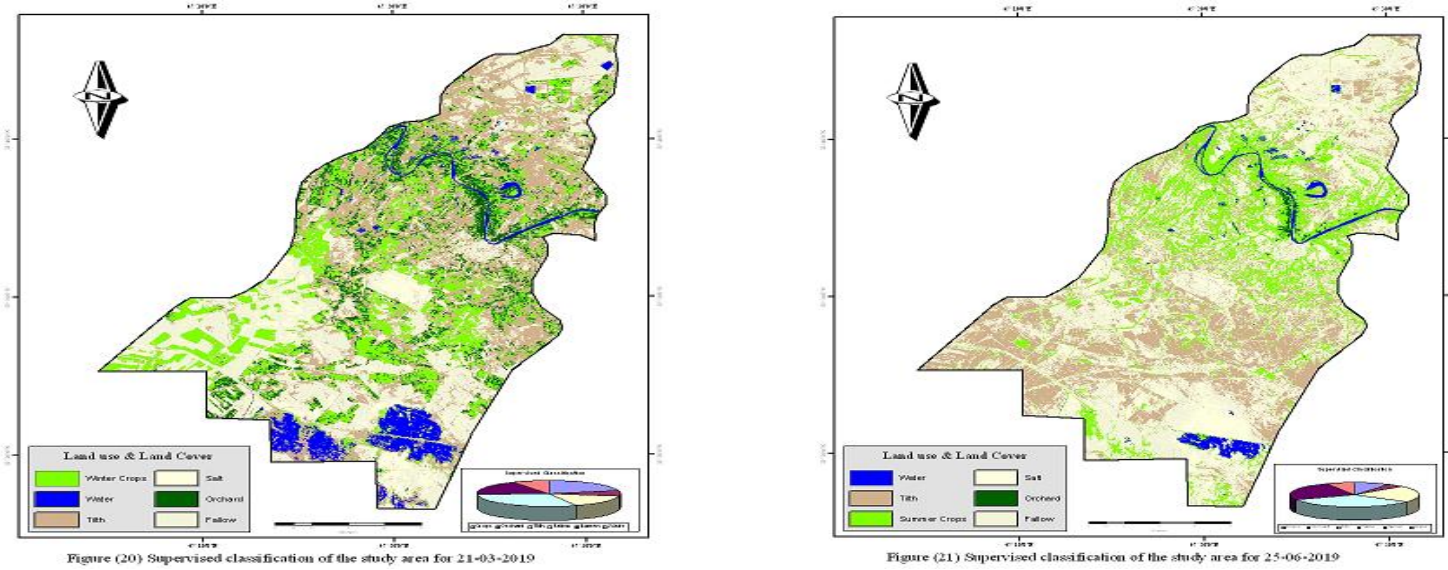


\subsubsection{Expert Classification}

The expert classification depending on the interpreter's experience to identifying the category using the elements of visual interpretation and ancillary references data, for building a geographical database using the ArcGIS software for the land use and land cover category in a vector format, and converting it into a raster format. Depending on the ERDAS IMAGINE software to build the expert classification which consists of two parts, the first is a knowledge engineer that consists of hierarchical decision trees are organized to identify hypotheses, rules, and conditions, the second is Knowledge Classifier provides an interface to apply the knowledge engineer classification to execute the classification output ${ }^{56}$. Using Error Matrix to evaluate the classification results and analyze errors ${ }^{57}$, the results indicated that the overall Accuracy was 90\%, producer's accuracy (omission error) 88\%, user's accuracy (commission error) $89 \%$, computation of Khat coefficient of agreement $87 \%$, these ratios are consistent with Anderson's criteria for classifying land use and land cover using remote sensing data.

Table (8) show the expert classification of land use and land cover, figure (22) shows the spatial distribution of land use and land cover categories in the study area as:

- Urban or built-up land: is comprised of intensive land use, it occupies 8514 ha (9\%) of the total study area. It includes Al-Noamaniya city, which is located on the right side of the Tigris River, occupies an area of 662 ha. $(0.7 \%)$, the rural settlements numbered 65 villages the distribution pattern is a clustered (-1.96 calculated by Arc GIS). Cities and villages are connected by a network of major and minor transportation routes (paved and unpaved), also the government centers (military base and airport).

- Agricultural land: used for the production of food and fiber etc, it occupies 70950 ha (75\%) of the total study area ${ }^{58}$, includes winter cropland such as wheat, barley, and winter vegetables (bean, onion, garlic, beet, cauliflower...) it covering the arable land and occupies 23650 ha. (25\%) of the total area, the barley occupies 16319 ha (23\%) of the winter cropland. Summer crops such as maize, rice, sunflower, cotton, and summer vegetables (cucumber, eggplant, tomato, okra, cowpea, onion...) and fodder (alfalfa and clover), it is cover the area near water sources and occupy 3784 ha (4\%) of the total study area. Palm orchards and fruit trees (evergreen and deciduous) distributed on both sides of the Tigris River, and occupy 2838 ha (3\%), of the total study area. The fallow lands cover most of the uncultivated lands and occupy 40678 ha $(43 \%)$ of the total study area.

- Rangeland: The herbaceous rangeland category naturally covered by grasses, its distribution on the western and eastern parts far from water sources and occupy 946 ha (1\%) of the total study area.

- Water: includes the areas that are constantly covered by water, such as Tigris River, irrigation canals and drainage, and oxbow lake (nonflowing, naturally enclosed bodies, U-shaped when the meander of a river is cut off), which occupies 1892 ha $(2 \%)$ of the total study area.

- Wetland: areas that are saturated or inundated by ground or surface waters it covers by marsh vegetation non-forested wetland, Delmaj Marshes covering in the southeastern parts which occupy 7568 ha (8\%) of the total study area.

- Barren land: it includes the areas that are constantly covered by sand, thin soil, and low vegetative cover, and a limited ability to support life occupies 4730 ha $(5 \%)$ of the total area. It covers dry salt flats near the Delmaj Marshes in the southeastern parts, occupies 3548 ha $(3.75 \%)$ of the total study area, and dunes, composed of dunes accumulations of sand transported by the wind in the southwestern parts, occupies 237 ha $(0.25 \%)$ of the total study area.

Table (8) expert classification of land use and land cover in the study area

\begin{tabular}{|c|c|c|c|c|c|}
\hline \multicolumn{2}{|c|}{ Level I } & \multicolumn{2}{|l|}{ Level II } & \multicolumn{2}{|l|}{ Level III } \\
\hline $\begin{array}{l}\text { Class } \\
\text { No. }\end{array}$ & Class Name & Class No. & Class Name & Class No. & Class Name \\
\hline \multirow{6}{*}{1} & \multirow{6}{*}{$\begin{array}{l}\text { Urban or } \\
\text { built-up land }\end{array}$} & \multirow{2}{*}{11} & \multirow{2}{*}{ Residential } & 111 & cities \\
\hline & & & & 112 & Village \\
\hline & & 12 & $\begin{array}{l}\text { Commercial } \\
\text { and Services }\end{array}$ & 121 & Government Centers \\
\hline & & \multirow{3}{*}{14} & \multirow{3}{*}{$\begin{array}{l}\text { Transportation, } \\
\text { Communications, } \\
\text { and utilities }\end{array}$} & 141 & Paved Routes \\
\hline & & & & 142 & Unpaved Routes \\
\hline & & & & 143 & Airport \\
\hline 2 & Agricultural Land & 21 & Cropland & 211 & Winter Cropland \\
\hline
\end{tabular}




\begin{tabular}{|c|c|c|c|c|c|}
\hline & & & & 212 & Summer Cropland \\
\hline & & & & 213 & Fallow \\
\hline & & 22 & Orchards & 221 & Mixed Orchards \\
\hline 3 & Rangeland & 31 & Herbaceous Rangeland & & \\
\hline \multirow{2}{*}{5} & \multirow{2}{*}{ Water } & 51 & Streams and Canals & 511 & Rivers and Canals \\
\hline & & 52 & Lakes & 521 & Small Lakes \\
\hline 6 & Wetland & 62 & Nonforested Wetland & 624 & Non-Tidal Marshes \\
\hline \multirow{2}{*}{7} & \multirow{2}{*}{ Barren Land } & 71 & Dry Salt Flats & & \\
\hline & & 73 & Sandy Areas & & \\
\hline
\end{tabular}

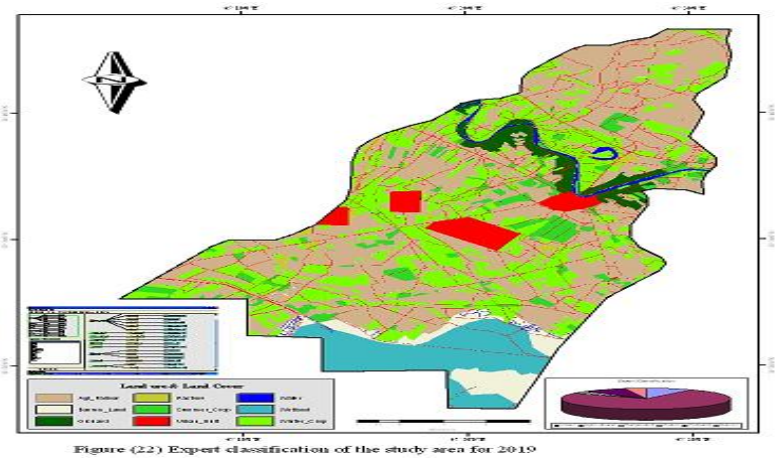

\section{BARLEY}

Barley (Hordeum vulgaire L.) a member of the Poaceae family ${ }^{59}$, It was one of the first domesticated grains in the Middle East region and Iraq specifically the Jarmo village about 10000 years ${ }^{60}$. Barley is important winter cereal crops in Iraq it comes after wheat in cultivated area and production ${ }^{61}$. Compared with other cereals barley has good tolerance of cold, drought, salt stress then, as a result, is commonly grown in marginal environments ${ }^{62}$. Barley is used as a livestock feed, as an important element in malt and beer industries, and preparing foods, etc ${ }^{63}$. The quality of barley is related to grain composition and structure through the supply of essential amino acids, phosphorus, protein and minerals, and energy content ${ }^{64}$.

Cultivated barley in the study area is a spring variety; despite to cultivated it in the winter season ${ }^{65}$. The cultivated barley productivity in the study area about (1520-1680) kg/ha, different barley seeds variety are used in the study area as local barley, Arifat, Marriott, Numar and IPA, Rihane, etc, the amount of the seeds used (100-120) kg/ha ${ }^{66}$.

Land assessment for barley cultivation depends on the climate, topography, wetness, soil characteristics, administration, and input level. To assessment barley requirement of climate characteristics during the growth cycle about five months (vegetative period, flowering period, and ripening period) ${ }^{67}$, precipitation should be well distributed at the growing cycle about $(500-1000) \mathrm{mm}^{68}$, in the study area barley depends on supplementary irrigation. Mean temperature in the growing cycle less than $20^{\circ} \mathrm{C}$, the optimum temperature $(20-22)^{\circ} \mathrm{C}$, the maximum temperature $(38-40)^{\circ} \mathrm{C}$, the minimum temperature $(4-5)^{\circ} \mathrm{C}$, chilling required for flowering, the low or medium relative humidity is desirable, and hot dry wind reducing the grain yield ${ }^{69}$.

Barley requirements of land characteristics; the topographic requirement depending on slopes, less than $2 \%$ are optimal under Irrigated agriculture and more than $4 \%$ is marginal. Slight floods during vegetative growth stage support barley cultivation but moderate floods constitute a severe limitation. Good to moderate drainage is optimal for barley cultivation, but the poor drainage is marginal.

Barley requirements of physical soil characteristics, fine to medium textured soils with good structure, are optimal while loamy sands with massive clay are marginal, soil depth more than $90 \mathrm{~cm}$ for roots development is optimal while depths less than $10 \mathrm{~cm}$ is marginal, calcium carbonate content less than $20 \%$ is optimal while more than $60 \%$ marginal, gypsum content less than $5 \%$ is optimal while more than $20 \%$ marginal $^{70}$.

Barley requires moderately fertile, the organic carbon content of more than $1.2 \%$ is optimal while less than $0.4 \%$ marginal, the optimal $\mathrm{pH}$ is (7.2-6) while (8.5-5.5) is marginal. Barley considered tolerant to salinity and alkalinity, the 
optimal ECe is (8-12) ds/m while more than (20-25) is marginal, ESP less than $15 \%$ is optimal while more than $45 \%$ is marginal $^{71}$.

\section{LAND SUITABILITY FOR BARLEY}

Land evaluation for barley cultivation in the study area depending on the Sys method by a combination of limitation method and parametric method for land suitability classification and land index ${ }^{72}$, depending on the FAO land suitability classification system, which consists of different categories (orders, classes, subclasses, and units) ${ }^{73}$. Application of geographic information systems to enter and storage spatial and attributes data to build a data bank (input stage), administrate and analyze then build a computer model for evaluating lands for barley cultivation in the study area (processing stage), display the results (output stage) table (9) figure (23) and figure (24) showing the spatial distribution of the actual and potential land suitability of barley cultivation in the study area.

Table (9) Actual and potential barley suitability in the study area

\begin{tabular}{|c|c|c|c|c|}
\hline \multirow{2}{*}{$\begin{array}{l}\text { Land Suitability } \\
\text { Land Mapping Unite }\end{array}$} & \multicolumn{2}{|c|}{ Actual Suitability } & \multicolumn{2}{|c|}{ Potential Suitability } \\
\hline & Land Index & Land Class. & Land Index & Land Class. \\
\hline E 2 & 64 & S2 fn & 81 & $\mathrm{~S} 1$ \\
\hline E 2.1, E 2.4, E 2.6 & 61 & $\mathrm{~S} 2 \mathrm{fn}$ & 81 & $\mathrm{~S} 1$ \\
\hline E 2.2 & 60 & S2 fn & 81 & $\mathrm{~S} 1$ \\
\hline E 2.3, E 2.7 & 44 & S3 fn & 81 & $\mathrm{~S} 1$ \\
\hline E 2.5 & 65 & S2 fn & 81 & $\mathrm{~S} 1$ \\
\hline E 6 & 55 & S2n & 88 & $\mathrm{~S} 1$ \\
\hline E 6.1 , E 6.4 & 74 & $\mathrm{~S} 2 \mathrm{n}$ & 88 & $\mathrm{~S} 1$ \\
\hline E 6.2, E 6.5 & 52 & $\mathrm{~S} 2 \mathrm{n}$ & 88 & S1 \\
\hline E 6.3 & 82 & $\mathrm{~S} 2 \mathrm{n}$ & 88 & $\mathrm{~S} 1$ \\
\hline E 11, E 11.2 & 78 & $\mathrm{~S} 1$ & 88 & $\mathrm{~S} 1$ \\
\hline E 11.1 & 86 & $\mathrm{~S} 1$ & 88 & $\mathrm{~S} 1$ \\
\hline E 11.3 & 60 & $\mathrm{~S} 2 \mathrm{n}$ & 88 & $\mathrm{~S} 1$ \\
\hline E14, E14.1 , E14.4 & 71 & S2 sf & 78 & $\mathrm{~S} 1$ \\
\hline E 14.2, E14.5, E14.8 & 66 & S2 sfn & 78 & $\mathrm{~S} 1$ \\
\hline E 14.3, E14.6 & 46 & S3 sfn & 78 & $\mathrm{~S} 1$ \\
\hline E 14.7 & 40 & S3 wsfn & 78 & $\mathrm{~S} 1$ \\
\hline A 3, A3.2 & 16 & N1 & 77 & S1 \\
\hline A 3.1 & 32 & S3 wn & 86 & $\mathrm{~S} 1$ \\
\hline A 3.3 & 13 & N1 & 86 & $\mathrm{~S} 1$ \\
\hline A 9 & 14 & N1 & 77 & $\mathrm{~S} 1$ \\
\hline A10, A10.1, A10.2, A10.5 & 16 & N1 & 57 & S2 f \\
\hline $\mathrm{A10.3}, \mathrm{A10.4}$ & 13 & N1 & 57 & $\mathrm{~S} 2 \mathrm{f}$ \\
\hline
\end{tabular}




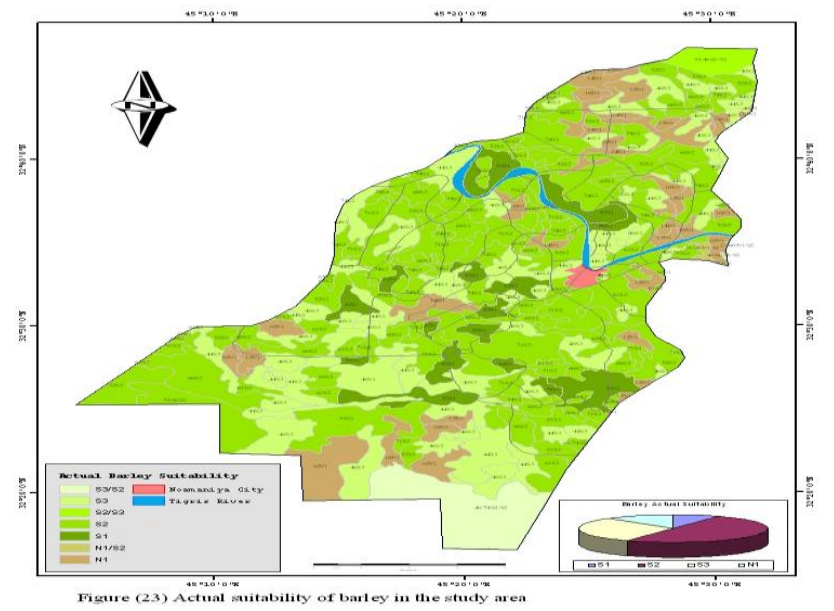

The results of evaluating suitability land characteristics of barley cultivation in the study area as:

- The climate characteristics (c) are defined by temperature, rainfall, and relative humidity then comparing with the barley growth periods requirements (vegetative, flowering, and ripening), results showing there are no important limitations, and the overall climate suitability is $\mathrm{S} 1$.

- The topography (t) is mostly defined by term of the slope, the slopes in the study area are flat to almost flat less than $2 \%$ for most land unites, there is no limitation and the suitability class is S1.

- The wetness (w) it is defined by drainage and flooding, the study area isn't exposed to flooding, and there are no limitations, the suitability class is $\mathrm{S} 1$, drainage is good for most land units and suitability class is S1, except land units A3.1, A3.3, A10.3, A10.4, E14.7 with a moderate limitation, and suitability class is S2. In the future, the limitations can be reclaimed to raise the potential land suitability.

- Physical soil characteristics (s) are defined by depth, texture, calcium carbonate, and gypsum. Depth is more than $90 \mathrm{~cm}$ for all land units, there are no limitations and the suitability class is S1. Soil texture for land units is clay, silty clay, silty clay loam, and silty loam, there are no limitations and the suitability class is $\mathrm{S} 1$. Calcium carbonate is more than $20 \%$ for most land units and the suitability class is S1, except the land unit E14, with a slight to moderate limitation and the suitability class is $\mathrm{S} 1 / \mathrm{S} 2$. Gypsum is less than $3 \%$ for most land units and the suitability class is S1 except the land units A9 and A10 with a slight limitation.

- Fertile soil characteristics (f) is defined by apparent CEC (cmol (+)/kg-1 clay), Acidity $\mathrm{pH} \mathrm{H}_{2} \mathrm{O}$, and organic carbonate OC \%. Apparent CEC is more than $24(\mathrm{cmol}(+) / \mathrm{kg}-1$ clay) for land units, there are no limitations and the suitability class is S1. Soil acidity $\mathrm{pH}$ is good for most land units and suitability class is

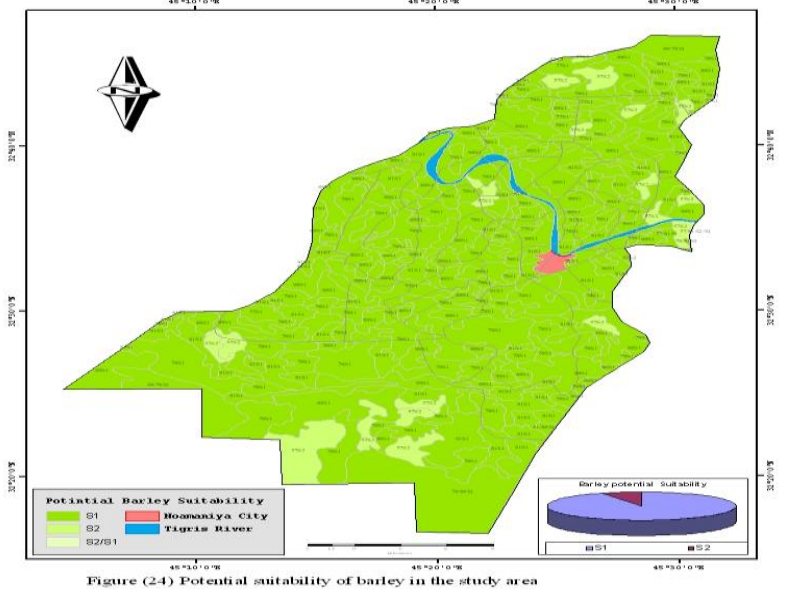

S1, except land units (E2, E2.1-E2.7) with a slight to moderate limitation, suitability class is $\mathrm{S} 1 / \mathrm{S} 2$, and the land units (A10, A10.1-A10.5) with a moderate to severe limitation, suitability class is S2/S3. Organic carbonate is more than $0.6 \%$ for most land units and the suitability class is S1, except the land units (E14, A10) with a slight to moderate limitation, and the suitability class is $\mathrm{S} 2$, In the future, the limitations can be reclaimed to raise the potential land suitability.

- The salinity and alkalinity soil characteristics (n); salinity (ECe) is less than $8(\mathrm{ds} / \mathrm{m})$ for all land units, there is no limitation, and the suitability class is $\mathrm{S} 1$, except land units (E2.3, E2.7, E6.2, E6.5, E11.3, A3.1, E14.3, E14.6, E14.7) with a moderate to severe limitation, suitability class is $\mathrm{S} 2 / \mathrm{S} 3$, and the land units (A9, A9.1-A9.3, A3, A3.2, A3.3, A10, A10.1-A10.5) with a severe limitation, suitability class is $\mathrm{N} 1$, in the future, the limitations can be reclaimed to raise the potential land suitability. Alkalinity (ESP) is less than $15 \%$ for all land units there is no limitation, and the suitability class is S1, except land units (E2, E2.1-E2.7) with a moderate limitation, suitability class is $\mathrm{S} 2$, and the land units (A3, A9) with a severe limitation, suitability class is $\mathrm{S} 3$, in the future, the limitations can be reclaimed to raise the potential land suitability.

The results of the land suitability classification of barley cultivation in the study area as:

- Suitability class S1: lands with high suitability because there are no limitations, this category includes the land units (E11, E11.1, E11.2), distributed in the southeast parts, central parts, and close to Tigris River, it occupies 7568 ha $(8 \%)$ of the total study area.

- Suitability class S2: lands with moderate suitability because there are slight to moderate limitations, of the physical, fertile, salinity and alkaline soil characteristics this category includes the land units (E2, E2.1, E2.2, E2.3, E2.4, E2.5, E2.6, E2.7, E6, E6.1, E6.2, E6.3, E6.4, E6.5), covers most of the study 
area except the parts of southern, southeastern and northern, it occupies 47350 ha $(50 \%)$ of the total study area, in the future, the limitations can be reclaimed to raise the potential land suitability.

- Suitability class S3: lands with marginal suitability because there are slight, moderate, and severe limitations, of the wet, physical, fertile, salinity and alkaline soil characteristics this category includes the land units (E14.3, E14.6, E14.7, A3.1), distributed in the southern, middle and northwestern parts of the study area, it occupies an area of 28,380 ha (30\%) of the total study area, in the future, the limitations can be reclaimed to raise the potential land suitability.

- Suitability class N1: lands actually unsuitable but potentially suitable because there are moderate, severe, and very severe limitations, of the wet, physical, fertile, salinity and alkaline soil characteristics this category includes the land units (A3, A3.2, A3.3, A9, A10, A10.1, A10.2, A10.3, A10.4, A10.5), distributed in the northwestern, northeastern, southeastern and southwestern parts of the study area, it occupies an area of 11,352 ha (12\%) of the total study area, in the future, the limitations can be reclaimed to raise the potential land suitability.

It is possible reclamation and improvement of some limitations of barley cultivation in the future to change land units suitability classification to the S1 and S2, which covered an area $93 \%$ and $7 \%$ respectively for each category in the study area.

\section{CONCLUSION}

- The study area located in the southeast part of Iraq, in the Wasit governorate. Climate according to Papadakis is a hot subtropical desert 3.272, according to Koppen is hot arid desert BWh. The topography is flat to almost flat and the notable landforms are the levees and irrigation channels. Soil classified in the study area into two orders (Entisol, Aridisols), two suborders
(Fluvents, Orthids), two great groups (Torrifluvents, Salorthids), six subgroups (Typic, Vertic, Aqueptic, Fluventic, Fluvaquentic, Gypsic). Hydrology Tigris River considers the main source for irrigation in the study area, groundwater is scarce with high soluble salts, and rainfall quantities are few and oscillated.

- Barley was one of the first domesticated grains in Iraq, it is an important winter cereal after wheat, occupy $23 \%$ of the winter cropland area, productivity about (1520-1680) kg/ha in the study area. The land evaluation depends on the barley requirements from climate, topography, wetness, soil characteristics, administration, and input level.

- Applying remote sensing by Landsat- 8 satellite image with the OLI sensor at 2019, by digital image processing and visual interpretation, for land use and land cover according to Anderson classification system, urban or built-up land occupies 9\%, agricultural land $75 \%$, rangeland $1 \%$, water $2 \%$, wetlands $8 \%$, barren land $5 \%$ of the total study area.

- Applying geographic information systems in the input stage, processing stage, and output stage, by depending on the Sys method by a combination of limitation method and parametric method, and the FAO land suitability classification system. Which showed land suitability for barley cultivation in the study area, S1 high suitability lands there are no limitations occupy $8 \%$, S2 moderate suitability lands because there are slight to moderate limitations occupy 50\%, S3 marginal suitability lands because there are slight, moderate, and severe limitations occupy 30\%, N1 unsuitable lands but potentially suitable because there are moderate, severe, and very severe limitations occupy $12 \%$. It is possible to reclamation and improvement some limitations of Barley cultivation in the future to change land suitability classification to the S1 and S2 which occupy an area 93\% and $7 \%$ respectively for each category in the study area.

\footnotetext{
${ }^{1}$ FAO, Land evaluation towards a revised framework, Rome, 2007, P 6.

${ }^{2}$ Edoardo A. C. Costantini, Manual of Methods for Soil and Land Evaluation, Italy, 2009, P 3.

${ }^{3}$ Gunther Fischer, Global Agro-ecological Assessment for Agriculture in the 21st Century Methodology and Results, Rome, 2002, P 4.

${ }^{4}$ FAO, Land quality indicators and their use in sustainable agriculture and rural development, Rome, 1998, P. 20.

${ }^{5}$ Mannava V.K. Sivakumar and others, Climate Change and Food Security in West Asia and North Africa, Springer, New York, 2013, P 27.

${ }^{6}$ A. P. A Vink, Land use Advancing, Springer-Verlag, Berlin, Heidelberg, New York 1975, PP 1-3.

${ }^{7}$ J. R. Anderson, and others, Land use and Land cover Classification System use with Remote Sensing Data, U.S.G.S. Professional Paper 964, 1976, 28 p.
} 
${ }^{8}$ Ir. C. Sys, E. Van Rants, Ir. J. Debareye, Land Evaluation, Agricultural publication No.7, Belgium, 1991.

${ }^{9}$ FAO, a Framework for Land Evaluation, soils bulletin 32, Rome, 1976.

${ }^{10}$ FAO, Land Evaluation for Rainfed Agriculture, Soil bull.52, Rome, 1983.

${ }^{11}$ FAO, Guide Lines, land evaluation for irrigated agriculture, soil bull.55, FAO, Rome, 1985.

${ }^{12}$ Ministry of Water Resources, State Commission on Survey, Administrative Iraq Map, Baghdad, 2019.

${ }^{13}$ Ministry of Higher Education \&Science Research, Space and Communications Directorate, Remote Sensing Center, Mosaic Satellite Images of Iraq, Baghdad, 2019.

${ }^{14}$ Ministry of Planning, Central Statistical Organization, Administrative Units and Their Area, (Unpublished Data), Baghdad, 2019.

${ }^{15}$ Ministry of Water Resources, General Directorate of Survey, Al- Noamaniya District Parcel Index, (Unpublished Data), Baghdad, 2019.

${ }^{16}$ Areas Calculated by ArcGIS Software.

${ }^{17}$ Papadakis, J., Climate of the world and their potentialities, Argentina, 1975.

${ }^{18}$ Kottek, Markus and Others, World Map of the Köppen-Geiger climate classification updated, Meteorologische Zeitschrift, Vol. 15, No. 3, 2006, P. 259-263.

${ }^{19}$ Ministry of Transportation, Iraqi Meteorological Organization and Seismology, Section of Climate, (Unpublished Data), Baghdad, (1988-2019).

${ }^{20}$ Ministry of Industry and Minerals, general directorate of Geological Survey and Mineral Investigation, Geological Report of Al-Kut, Baghdad, 1992.

${ }^{21}$ Consulting Engjneering Bureau, Middle Tigris Irrigation Project, Collage of Engineering, University of Baghdad, vol. 1, Baghdad, 1997.

${ }^{22} \mathrm{http}: / /$ srtm.csi.cgiar.org

${ }^{23}$ USDA, Soil Survey Manual, Agric. Handbook, No.18, Washington D.C. 1951, 503 p.

${ }^{24}$ USDA, Soil Taxonomy a basic system of soil classification for making and interpretation soil survey, Soil conserve. Service, Agric. Handbook No.436, 1975, 754 p.

${ }^{25}$ F. Newhall, A compilation by using mathematical model calculated soil moisture regime of Africa, USA, 1972.

${ }^{26}$ Jawahar L. Sehgal, et al., The soils of the Middle Tigris Project for land use planning, General Establishment for Soil Studies \& Designs, State Organization for Soil \& Land Reclamation, Baghdad, Iraq, 1980.

27 Ibrahim J. Mohammad, a Unified National soil Legend for Iraqi Soils, Directorate General of Water Resources Management, Baghdad, 2009.

${ }^{28}$ Waleed K. Al-Agidi, Pedology Soil Survey and Classification, Baghdad, 1986, p. 337.

${ }^{29}$ Ahmad S. Al-Mashhadani, Soil Surveying and Classification, Mosul, 1994, p. 215.

${ }^{30}$ Waleed K. Al-Agidi, Soil Managgment and Landuse, Baghdad, 1990, pp. 578-583.

${ }^{31}$ Ministry of Water Resources, National Center for Water Resources Management, (Unpublished Data), Baghdad, 2019.

${ }^{32}$ Ministry of Agriculture, General Directorate of Agriculture in Wasit, Numaniyah Agriculture Directorate, Planning Department, Wasit, 2019.

${ }^{33}$ US Salinity Laboratory Staff, Diagnosis and improvement of saline and alkali soils. US Department of Agriculture Handbook 60, Washington, DC, 1954.

${ }^{34}$ Ministry of Irrigation, General Directorate for Irrigation and Reclamation Projects, Technical Report of the Middle Tigris Project, Baghdad, 1999.

${ }^{35}$ Mayada F. M. Alobeidi, Sustainable use of Biological Diveristy in Hor Dalmaj and Role in Environmental Protection, Master in Geography, Collage of Basic Education, Univesity of Al-Mustatansiriiya, 2019.

${ }^{36}$ Saleh M. Al-Mutlaq and Husam S. Jabr, Groundwater Exploitation in Iraq and Pollution, The Arab Gulf Magazine, Volume XIII, No. 3, University of Basra, 1981, P. 78.

${ }^{37}$ Ministry of Higher Education \&Science Research, Space and Communications Directorate, Remote Sensing Center, Archive Department, Baghdad, 2019.

38 J. R. Anderson and others, A land use land cover classification system for use with remote sensing data, Geological Survey professional paper 964, 2002, 39 p.

${ }^{39}$ Rozenstein, K Arnon, Comparist of Methods for Land-use Classification in Corporating Remote Sensing and GIS Inputs, University of the Negev, 2011, P. 27. 
${ }^{40}$ Leica GeoSystem, ERDAS Field Guide, USA, 2003.

${ }^{41}$ Rafael C. Gonzalez, and Richard E. Woods, Digital Image Processing, $2^{\text {nd }}$ ed., Prentice-Hall, Inc., USA, 2002 , P.1.

${ }^{42}$ Nickolas L. Faust, Image Enhancement, New York, 1989, P.3.

${ }^{43}$ Tucker, C. J., Red and photographic infrared linear combinations for monitoring vegetation, Remote Sens. Environ. 1979, PP. 127-150.

44 Tso, Brandt and Paul M. Mather, Classification Methods for Remotely Sensed Data, Taylor \& Francis, London، 2001, P.8.

${ }^{45}$ Kim, Y., Huete, A. R., Miura, T., Jiang, Z., Spectral compatibility of vegetation indices across sensors: band decomposition analysis with Hyperion data, J. Appl. Remote Sens 4, 2010.

${ }^{46}$ John R. Jensen, Introductory Digital image processing: A Remote Sensing Perspective, 4th Edition, University of South Carolina, 2015, P. 14.

47 Huete A., Overview of the radiometric and biophysical performance of the MODIS vegetation indices, Remote Sensing of Environment 83, 2002, PP. 195-213.

${ }^{48}$ C. J. Tucker, Red and photographic infrared linear combinations for monitoring vegetation, Remote Sens. Environ 8 , 1979, PP. 127-150.

${ }^{49}$ Genesis T. Yengoh et al., Use of the Normalized Difference Vegetation Index (NDVI) to Assess Land Degradation at Multiple Scales, SpringerBriefs in Environmental Science, 2015.

${ }^{50}$ A.R. Huete, A Soil-Adjusted Vegetation Index (SAVI). Remote Sens. Environ 25. 1988, PP. $295-309$.

${ }^{51}$ Di Gregorio A., Jansen, L. M., A new Concept for Land Cover Classification System LCCS Classification Concepts and user Manual, FAO. 2000.

${ }^{52}$ Thomas M. Lillesand, Jonathan W. Chipman Ralph W. Kiefer, Remote Sensing and Image Interpretation, 7th Ed., John Wiley \& Sons, USA, 2015, PP 556-560.

53 Ismat Mohammed El-Hassan, Digital Image Processing in Remote Sensing, King Saud University, College of Engineering, 2007, P. 130.

${ }^{54}$ Sabins, Floyd F. Jr. , Remote Sensing Principles and Interpretation, $2^{\text {nd }}$ ed., Remote Sensing enterprises, Inc., USA, 1985, P 269.

55 James B. Campbell, Randolph H. Wynne, Introduction to Remote Sensing, 5th Ed., Guilford Press, USA, 2011, PP 359-360.

${ }^{56}$ Leica GeoSystem, ERDAS IMAGINE Spatial Modeling and Expert Systems, ERDAS education service, Atlanta, USA, 2002.

${ }^{57}$ Russell G. Congalton and Kass Green, Assessing the Accuracy of Remotely Sensed Data: Principles and Practices, ${ }^{2}$ nd ed., Taylor \& Francis Group, USA, 2009, 183 P.

${ }^{58}$ Ministry of Agriculture, General Directorate of Agriculture in Wasit, Al- Noamaniya Agricultural office, planning section, (unpublished data), Wasit, 2019.

${ }^{59}$ Wendy A. Harwood, Barley Methods and Protocols, Springer Nature, USA, 2019, P 1.

${ }^{60}$ Zohary D, Hopf, Domestication of Plants in the Old World: The Origin and Spread of Cultivated Plants in West Asia, Europe, and the Nile Valley, 3rd ed., Oxford University Press, 2000. PP. 59-69.

${ }^{61}$ Ahmed A. Al-Karhi, Effect of Nitrogen Sulfur Levels and Number of Cutting on Some of Growth Traits Yield of Green Forage and Grains of Barley, Ph.D. dissertation, Baghdad University, Agriculture College, 2014 , P 1.

${ }^{62}$ S. Ullrich, Significance, adaptation, production, and trade of barley. Barley: production, improvement, and uses, Blackwell, New York, 2011, PP. 3-13.

${ }^{63}$ Steven E. Ullrich, Barley Production Improvement and Uses, Wiley-Blackwell, 2011, PP 478-562.

${ }^{64}$ Ulla Holopainen-Mantila, Composition and structure of barley (Hordeum vulgare L.) grain in relation to end uses, Doctoral dissertation, Faculty of Biological and Environmental Sciences, University of Helsinki, Finland, 2015.

${ }^{65}$ Abbas L. Al-Qaisi, Response of Genotypes from Barley Hordeum vulgare L. to frequent Grass and Grain Production, Master Thesis, College of Agriculture, University of Baghdad, 2001, p1.

${ }^{66}$ Ministry of Agriculture, General Directorate of Agriculture in Wasit, Al- Noamaniya Agricultural office, planning \& Technical section, (Unpublished Data), Wasit, 2019.

${ }^{67}$ Aqil J. Al-Husseiny, The effect of cycocel and nitrogen on the growth and yield of barley crop on different dates, doctoral thesis, College of Agriculture, University of Baghdad, 1996, p 129. 
${ }^{68}$ A. R. Nilan \& E. S. Ullrich, Barley: taxonomy, origin, distribution, production, genetics \& breeding. Barley: Chemistry and Technology, American Association of Cereal Chemists, Inc, USA, 1993.

${ }^{69}$ Ali H. Mussa, Climate and Agriculture, $1^{\text {st }}$ ed., Damascus, 1994, p 34.

${ }^{70}$ Hussein F. Jassim, Principles of Regional Soil Survey Land Evaluation and Land use Planning in Iraq. Ph.D. Thesis, University of Ghent, Belgium, 1981, PP 267- 270.

${ }^{71}$ Ir. C. Sys and others, Land Evaluation, Part III Crop Requirements, Agriculture Publication No.7, Belgium, 1993. PP. 25-27.

${ }^{72}$ Ir. C. Sys, E. Van Rants, Ir. J. Debareye, Land Evaluation, Part I \& II, Agricultural publication No.7, Belgium, 1991.

${ }^{73}$ FAO, a Frame work for Land Evaluation, Soil bulletin 32, FAO, Rome, 1976. 